\title{
PHARMACOKINETICS OF CIPROFLOXACIN AND ITS INTERACTION WITH DICLOFENAC AFTER INTRAVENOUS INJECTION IN HEALTHY RABBITS
}

\author{
Shaheen H.M. ${ }^{1}$, El-Sheikh M.W. ${ }^{2}$ \\ ${ }^{1}$ Department of Pharmacology, Faculty of Veterinary Medicine, \\ South Valley University, Qena, Egypt. \\ ${ }^{2}$ Animal Health Research Institute, Tanta Provincial Lab., Egypt.
}

\begin{abstract}
The purpose of this study was to determine the pharmacokinetics and possible interactions of ciprofloxacin and diclofenac in healthy rabbits following intravenous injection. Six male adult chinchilla rabbits were used for the study. In a cross-over design $(3 \times 2)$ was used in two phases separated by a wash period ( 3 weeks), Ciprofloxacin was injected at a dose of $30 \mathrm{mg} \mathrm{kg}^{-1}$. They were given intravenously while diclofenac sodium at recommended dose at level of $1 \mathrm{mg} \mathrm{kg}^{-1}$, i.m. to each healthy rabbit. The concentration-time data were analyzed by two-compartmental (after i.v. dose). Plasma concentrations of ciprofloxacin were determined by HPLC. After a washout period, after the drugs were co-administered. The kinetic parameters of ciprofloxacin were significantly changed by administration of diclofenac. Based on these kinetic data, ciprofloxacin is likely to be effective in rabbits even in combination with diclofenac and suggested for treating infections caused by drugsensitive pathogens in rabbits.
\end{abstract}

Keywords: Ciprofloxacin, Diclofenac, Pharmacokinetics, Rabbit, Plasma Concentration. 


\section{INTRODUCTION}

Ciprofloxacin (CFX) is a fluoroquinolone derivative with outstanding antibacterial activity against gram-negative and some grampositive bacteria as well as on some Chlamydia and Mycoplasma, and many Mycobacterium species (Neu 1987, Campoli-Richards et al. 1988, Hyatt et al. 1994). Its action takes place via the inhibition of the bacterial DNA gyrase which is an essential enzyme for DNA replication and synthesis. In animals quinolones, especially CFX, exhibit favorable pharmacokinetic properties, their apparent volume of distribution suggested substantial tissue penetration (Abd El-Aty et al. 2005, Albarellos et al. 2004).

Diclofenac (2-[(2,6-dichlorophenyl)amino]phenylacetate) is one of the most frequently used non-steroidal anti-inflammatory drugs (NSAIDs) which share similar anti-inflammatory, analgesic, and antipyretic properties. These NSAIDs exert many of their effects through the inhibition of cyclooygenase (COX), diclofenac was approximately equipotent against both COX I and II isoforms (Furst 1997, Lin et al. 2006) Although its toxicity is commonly associated with the gastrointestinal tract (Wallace 1997) and with idiosyncratic hepatic injury (Boelsterli 2003) there appeared to be a direct link of diclofenac to severe, acute renal failure and massive scale of diclofenac poisoning was due to the fact that this drug was concentrated in the kidney and liver of domestic livestock. Diclofenac also damages the kidneys of rainbow trout and rabbits (Schwaiger et al. 2004, Taib et al. 2004). Ingested diclofenac residues were found to be more concentrated in the kidneys of buffalo and goat compared to their respective livers (Oaks et al. 2004). 
Antimicrobials and non-steroidal anti-inflammatory drugs (NSAIDs) are used concomitantly and pharmacokinetic interactions between them have been previously described by (Kampmann et al. 1972, Carbon et al. 1984).

In present study the influence of diclofenac on the pharmacokinetic behavior of CFX in rabbit was investigated. The changes in pharmacokinetic profile may result in altered sensitivity of CFX requiring a new basis of drug selection and dosage modification.

\section{MATERIAL AND METHODS}

\section{Experimental animals:}

Based on physical and blood analytical examination, six clinically healthy male adult rabbits of Chinchilla strain, aged 6-8 months; weighing $3.3 \pm 0.15 \mathrm{~kg}$, They were randomly selected for the pharmacokinetic study and had not received any drugs within one month prior to beginning of the study. The rabbits were acclimatized to research setting and received a standard and a drug-free diet and water ad libitum. For each treatment period of the cross-over, they were observed daily for general health, and clinical observations were made prior to injection and at 2, 10 and $24 \mathrm{~h}$ post-injection.

\section{Drug administration:}

Ciprofloxacin (Ciprofloxacin ${ }^{\circledR}$, al-amrya, 2mg/ml) at a dose of 30 $\mathrm{mg} \mathrm{kg}^{-1}$ (as mentioned before by Yoon et al. (1994). The drug was given to each rabbit, by a catheter implanted in the central vein of the ear (as a 
control group). A second catheter was inserted in the opposite ear to take blood $(0.5 \mathrm{ml})$ at different times, in a cross-over design $(3 \times 2)$ was used in two phases.After a washout period of three weeks the drug was again given to the same animals at the same dose rate followed immediately by diclofenac sodium (Dicloflame ${ }^{\circledR}, 2.5 \%$ Unipharma Elobour city, Egypt) at recommended dose at level of $1 \mathrm{mg} \mathrm{kg}^{-1}$, intramuscularly (i.m.) at the thigh muscle.

\section{Sampling procedure:}

Two different syringes were used for each drug. In both the studies, blood samples were collected into heparinised glass centrifuge tubes, at $0.00,0.08,0.25,0.50,0.75,1,1.5,2,4,6,8,10,12,24,30,36$ and $48 \mathrm{~h}$ post administration.

Plasma was recovered after centrifugation at 1500 r.p.m. for 15 min, and samples were stored at $-20^{\circ} \mathrm{C}$ until analysis.

\section{Drug analysis:}

Concentrations of ciprofloxacin in plasma were estimated by the method described by Nielsen \& Gyrd-Hansen (1997) using High Performance Liquid Chromatography (HPLC). Estimation of concentration was carried out by interpolating CFX peak areas on a calibration curve of spiked the blank plasma over the range assayed. The sensitivity of the method was $0.01 \mu \mathrm{g} / \mathrm{ml}$.

The extent of plasma protein binding was determined in vitro using an ultrafiltration technique as described by Craig \& Suh (1991). 


\section{Pharmacokinetic analysis:}

The pharmacokinetic parameters were analyzed using a twocompartment open model system with help of computerized curvestripping program a computerized curve-stripping program (R Strip; Micromath Scientific Software, Salt Lake City, UT, USA) was used to analyze the concentration-time curves for each individual after the administration of ciprofloxacin.

The pharmacodynamic efficacy of ciprofloxacin was determined by calculation of $\mathrm{C}_{\max } / \mathrm{MIC}$ and $\mathrm{AUC}_{24} / \mathrm{MIC}_{90}$ ratios following i.v. administration of the drug using the relevant mean $\mathrm{MIC}_{90}$ reported values $<0.03 \mu \mathrm{g} / \mathrm{mL}$ (Ellie et al. 1988) and 0.12 to $0.49 \mu \mathrm{g} / \mathrm{mL}$ (Kang et al. 1994 and Kumar et al. 2002).

\section{Statistical analysis:}

The descriptive data are presented as mean \pm SE values. The mean plasma pharmacokinetic variables for ciprofloxacin were statistically compared between rabbits by using Wilcoxon's Rank Sum test for significant differences testing of these parameters (SPSS, Release 9.0 for windows).

\section{RESULTS}

All rabbits were clinically healthy throughout the experiment. There were no identifiable reactions following administration of ciprofloxacin or diclofenac treatments by i.v. and i.m. routes. The mean plasma concentration-time profile of ciprofloxacin (30 $\mathrm{mg} \mathrm{kg}^{-1}$ ) following single i.v. and interaction with diclofenac administration (1 mg $\mathrm{kg}^{-1}$ ) are presented graphically in Figure I. Pharmacokinetic parameters based on two compartments method are presented in Table I.. 
The values of the pharmacokinetic determinants in the ciprofloxacin and diclofenac treated rabbits are given in Table I and Figure 1.

The values of the ciprofloxacin distribution phase revealed significant changes between the two groups. Diclofenac treatment was significantly prolonged the values for ciprofloxacin half-live of distribution $\left(\mathrm{T}_{1 / 2 \alpha}\right), 0.49 \pm 0.001 \mathrm{~h}$ against $0.34 \pm 0.001 \mathrm{~h}$ in control animals. Also, diclofenac treatment was significantly delayed the values for zero time plasma ciprofloxacin concentration intercept of regression line of absorption phase (A), $8.26 \pm 0.12 \mu \mathrm{g} / \mathrm{ml}$ against $5.53 \pm 0.04 \mu \mathrm{g} / \mathrm{ml}$ in control group. The findings of the present study further revealed significantly unchanged values of ciprofloxacin $(\alpha)$ values $\left(2.03 \pm 0.02 \mathrm{~h}^{-1}\right.$ in control rabbits against $1.40 \pm 0.05 \mathrm{~h}^{-1}$ in diclofenac treated rabbits).

As a result of diclofenac treatment the indicators of ciprofloxacin distribution in the body i.e. volume of distribution at steady state $\left[\mathrm{V}_{\mathrm{dss}}\right]$ and volume of central compartment $\left[\mathrm{V}_{\mathrm{c}}\right]$ were significantly unchanged between the treated rabbits, $2.61 \pm 0.002 \mathrm{~L} / \mathrm{kg} ; 1.67 \pm 0.001 \mathrm{~L} / \mathrm{kg}$ when compared with the control group $2.44 \pm 0.001 \mathrm{~L} / \mathrm{kg} ; 1.49 \pm 0.004 \mathrm{~L} / \mathrm{kg}$ respectively. Whereas, apparent volume of distribution $\left[\mathrm{V}_{\mathrm{d}(\text { area })}\right]$, were significantly changed between the treated rabbits $6.24 \pm 0.22 \mathrm{~L} / \mathrm{kg}$ when compared with the control group $4.11 \pm 0.13 \mathrm{~L} / \mathrm{kg}$

Treatment of rabbits with diclofenac was unchanged the elimination half life of difloxacin $\left(\mathrm{t}_{1 / 2 \beta}\right)$. The elimination half life was $2.35 \pm 0.11 / \mathrm{h}$ in diclofenac treated against $2.42 \pm 0.06 / \mathrm{h}$ in control animals. The total body clearance $(\mathrm{ClB})$ however, showed significant difference in the diclofenac treated rabbits $1.84 \pm 0.001(\mathrm{ml} / \mathrm{h}) / \mathrm{kg}$ as compared with Kafrelsheikh Vet. Med. J. Vol. 9 No. 1 (2011) 
control group $(1.17 \pm 0.001 \mathrm{ml} / \mathrm{h} / \mathrm{kg})$. On the other side, the zero time intercept of the elimination phase (B) represented a significant difference between the two treated groups, $(6.75 \pm 0.06 \mu \mathrm{g} /) \mathrm{ml}$ in control group and $3.24 \pm 0.10 \mu \mathrm{g} / \mathrm{ml}$ in diclofenac treated rabbits.

In the diclofenac treated rabbits, the area under curve (AUC), were significantly lower $(\mathrm{p} \leq 0.001) \quad 16.28 \pm 1.47(\mu \mathrm{g} . \mathrm{h}) / \mathrm{ml}$ and $25.55 \pm 1.52$ $(\mu \mathrm{g} . \mathrm{h}) / \mathrm{ml}$, respectively, against the control animals. While, values of the mean residential time (MRT) values were significantly unchanged 2.07 \pm 0.12 , than $2.82 \pm 0.03 / \mathrm{h}$ respectively, in control animals.

The in vitro MIC of ciprofloxacin using Pasteurella multocida (isolated strain) was found to be $\mathrm{MIC} \leq 0.083 \mu \mathrm{g} \mathrm{ml}^{-1}$ for rabbits after i.v. dosing alone and $\mathrm{MIC} \leq 0.079 \mu \mathrm{g} \mathrm{ml} \mathrm{m}^{-1}$ in combination with diclofenac.Protein binding assay for ciprofloxacin was $29.6 \pm 2.38 \%$

\section{DISCUSSION}

Antimicrobial agents and non-steroidal anti-inflammatory drugs (NSAIDs) are often concomitantly used to treat endotoxaemia in rabbits. The distribution and elimination of antimicrobial agents in horses (Whittem et al. 1996, el-Banna 1999) and dogs (Ogino et al. 2005) were altered by being co-administered with NSAIDs.

Ciprofloxacin distribution parameters are revealed, accelerated ciprofloxacin half-live of distribution $\left(\mathrm{T}^{1} / 2 \alpha\right)$, also, diclofenac treatment was significantly delayed the values for zero time plasma ciprofloxacin concentration intercept of regression line of absorption phase (A). Diclofenac treatment was clearly affect on apparent volume of distribution $[\mathrm{Vd}($ area $)]$, was significantly changed between the treated 
rabbits $(6.24 \pm 0.22 \mathrm{~L} / \mathrm{kg})$ compared with the control group $4.11 \pm 0.13$ L/kg. Our data were explained by Connell et al. (1987) who mentioned that raised blood pressure, caused marked antinatriuresis and expansion of extracellular fluid and plasma volume, and raised glomerular filtration rate in humans, as demonstrated by inulin clearance test. All nonsteroidal antiinflammatory drugs (NSAIDs) in doses adequate to reduce inflammation and pain can increase blood pressure in both normotensive and hypertensive individuals (Warner \& Mitchell 2008). So, could be the cause of elevated ciprofloxacin half-live of distribution $\left(\mathrm{T}^{1} / 2 \alpha\right)$ and apparent volume of ciprofloxacin distribution [ $\mathrm{Vd}($ area $)]$ values due to diclofenac treatment. Similar results obtained by Post et al.(2003) who mentioned that volume of distribution at steady state was significantly increased in the dexamethasone-treated pigs.Dexamethasone significantly increased the terminal elimination half-life of enrofloxacin.

Unfortunately the results were disagreed to these obtained by Elmas et al. (2008) who reported that the distribution values of enrofloxacin $\left(\mathrm{T}^{1 / 2} \alpha\right)$ and $[\mathrm{Vd}($ area $)]$ were decreased significantly in endotoxaemic rabbits, as may be attributed to the physiological status of the tested animals. Similar results for Klebsiella pneumoniae O3 lipopolysaccharide (LPS) dramatically decreased the biliary excretion of cefoperazone. The LPS-induced decrease in the biliary excretion of CPZ may be caused by an inhibition of the anion transport system across the sinusoidal and/or bile canalicular membrane (Haghgoo et al. 1995). Rao et al. 2000 have found that the fraction of enrofloxacin metabolized to ciprofloxacin was $28.8 \%$. The $\mathrm{C}_{\max }, \mathrm{t}_{1 / 2 \beta}, \mathrm{AUC}$ and MRT of ciprofloxacin in normal goats were $0.45 \mu \mathrm{g} / \mathrm{mL}, 1.79 \mathrm{~h}, 1.84 \mu \mathrm{g} . \mathrm{h} / \mathrm{mL}$ and $3.34 \mathrm{~h}$, 
respectively. As compared with normal goats, the values of $t_{1 / 2 \beta}(1.83 \mathrm{~h})$, AUC $(11.68(\mu \mathrm{g} . \mathrm{h}) / \mathrm{ml})$ and MRT $(2.13 \mathrm{~h})$ of enrofloxacin were significantly higher, whereas its $\mathrm{Cl}_{\mathrm{B}}(430 \mathrm{~mL} / \mathrm{h} / \mathrm{kg})$ and metabolite conversion to ciprofloxacin (8.5\%) were lower in febrile goats. The $\mathrm{C}_{\max }$ $(0.18 \mu \mathrm{g} / \mathrm{mL})$ and AUC $(0.99 \mu \mathrm{g} . \mathrm{h} / \mathrm{mL})$ of ciprofloxacin were significantly decreased, whereas its $\mathrm{t}_{1 / 2 \beta}(2.75 \mathrm{~h})$ and MRT $(4.58 \mathrm{~h})$ were prolonged in febrile than in normal goats.

Many factors can affect drug plasma levels in disease states, so changes in drug distribution must be explained cautiously. The increased volume of drug distribution for penicillin $G$ has been reported in dogs suffering from a generalized streptococcal or Pseudomonas aeruginosa infection, and for quinine during febrile episodes in patients with malaria.

AUC values of ciprofloxacin, in the diclofenac treated rabbits were statistically significant reduction. This reduction may be attributed to the higher osmolarity, interfering with rapid absorption of drug or due to less affinity in aqueous compartment of the drug (Bashir et al. 2008). Previous studies in water deprivated rats, it was suggested that, in view of the significant changes in the disposition characteristics of salicylates with water deprivation, due care must be exercised in adjusting doses giving proper consideration to body hydration levels (Bakar \& Niazi 1983). Also, studies in water deprivated rabbits, results reflected that water deprivation had a profound effect leading to change in the bioavailability and disposition kinetics of piroxicam which suggested an adjustment of dosage regimen in clinical condition (Irfan et al. 1999). 
The total body clearance (ClB) however, showed significant delayed in the diclofenac treated rabbits. This may attributed to the intestinal tract as an important pathway in eliminating ciprofloxacin and other fluoroquinolones (Ramon et al. 1996) beside glomerular filtration (Vancutsem et al. 1990). Ogino et al. (2005) have found a decrease in the clearance of drugs from circulation after enrofloxacin and flunixin meglumine were co-administered, suggesting that enrofloxacin and flunixin meglumine interact during the elimination phase of drugs. Vancutsem et al. (1990) reported that fluoroquinolones occur via glomerular filtration and active tubular secretion by anion transport system. Soma et al. (1988), Ogino et al. (2005), also reported that flunixin meglumine involves renal tubular section in some animals. Miyazaki et al. (2001) reported that the elimination of flunixin meglumine in rabbits was mainly due to non-renal routes, including biotransformation in the liver. The renal clearance was only one-tenth of total body clearance. Dexamethasone increased enrofloxacin total body clearance. However, dexamethasone did not affect the metabolism of enrofloxacin and actually decreased the total amount of drug (enrofloxacin and ciprofloxacin) recovered in the urine. Whereas minimal plasma levels of ciprofloxacin were observed in pigs given dexamethasone, suggests that dexamethasone is increasing fecal drug elimination or may be due to increased glomerular filtration rate (Post et al. 2003).

Early studies in animals and man (Riess et al. 1978, Stierlin et al. 1979) showed that diclofenac undergoes an extensive hepatic metabolism involving aromatic hydroxylations and conjugations. It has been recently 
described how CYP-mediated metabolic activation of the drug and the formation of reactive metabolite(s) by drug oxidation is related to diclofenac hepatotoxicity (Schmitz et al. 1992, Bort et al. 1999). Also, the mitochondrion is clearly a target of diclofenac-induced nephrotoxicity as demonstrated by the oxidative stress and massive DNA fragmentation reported from studies with diclofenac in vivo (Hickey et al. 2001). These factors could affect the physiological effect of the rabbits . Alter the biotransformation or excretion of ciprofloxacin and so, could affect its kinetic parameters.

On the other side, the zero time intercept of the elimination phase (B) represented a significant difference between the two treated groups, $6.75 \pm 0.06 \mu \mathrm{g} / \mathrm{ml}$ in control group and $3.24 \pm 0.10 \mu \mathrm{g} / \mathrm{ml}$ in diclofenac treated rabbits, which could be attributed to ciprofloxacin, was rapidly distributed and that was confirmed by short ciprofloxacin half-live of distribution

The interaction between antibiotics and serum proteins is a dynamic reversible process, and drug molecules are constantly binding and unbinding at a rapid pace In MIC studies, the presence of 40 to $50 \%$ serum does not alter the in vitro potency of ciprofloxacin (Blaser et al. 1986).

Protein binding has long been considered one of the most important physicochemical characteristics of drugs, playing a potential role in distribution, excretion and therapeutic effectiveness (Turnidge 1999). The in vitro protein binding percentage of difloxacin in goat plasma ranged from $29.5-42.4 \%$, It was comparable to moxifloxacin in camels 
and sheep , 33-40.9\% at concentrations from 0.156 to $5.0 \mu \mathrm{g} / \mathrm{mL}$ ( $\boldsymbol{A} \boldsymbol{b \boldsymbol { d }}$ El-Aty et al. 2007, Goudah 2007), but lower than in humans, 55\% and dogs, $71 \%$ ( Siefert et al. 1999). The higher bound fraction in dogs may be due to great albumin affinity of difloxacin in canine plasma.

Since fluoroquinolones are drugs that act in a concentrationdependent manner, it is considered that the ratios $\mathrm{C}_{\max } / \mathrm{MIC}_{90}$ and $\mathrm{AUC}_{0-}$ ${ }_{24} / \mathrm{MIC}_{90}$ are the best parameters for predicting antimicrobial effect (Lode et al. 1998). Fluoroquinolones a $\mathrm{C}_{\max } / \mathrm{MIC}_{90}>3.0$ produced a $99 \%$ reduction in bacterial count, and values $\geq 8.0$ prevented the emergence of resistant organisms (Craig 1998). Furthermore an $\mathrm{AUC}_{0-24} / \mathrm{MIC}_{90}$ value of >100 should be achieved to give maximum clinical and bacteriological efficacy (Turnidge 1999). Fluoroquinolones have low MIC values against many Gram-negative bacteria (Walker 2000). MICs $(\mu \mathrm{g} / \mathrm{ml})$ of ciprofloxacin for S. aureus; E. faecalis; P. aeruginosa; E. coli, were within the accepted ranges $0.12-0.5 ; 0.25-2 ; 0.25-1 ; 0.004-$ 0.015, respectively (Riddle et al. 2000). It would therefore appear likely that ciprofloxacin at $30 \mathrm{mg} / \mathrm{kg}$ given by the i.v. route may be useful in treating infections caused by bacteria sensitive to ciprofloxacin in rabbits. MIC was found to be $\leq 0.083 \mu \mathrm{g} \mathrm{ml}^{-1}$ for rabbits after i.v. dosing alone and $\mathrm{MIC} \leq 0.079 \mu \mathrm{g} \mathrm{m} \mathrm{m}^{-1}$ in combination with diclofenac using Pasteurella multocida (isolated strain).

The present data suggest that ciprofloxacin could likely to be effective in rabbits even in combination with diclofenac and suggested for treating infections caused by drug-sensitive pathogens in rabbits. 
Table (1): Comparison of kinetic parameters of ciprofloxacin administered intravenously (30 mg kg$\left.{ }^{-1}\right)$ in control and diclofenac $\left(1 \mathrm{mg} \mathrm{kg}^{-1}\right)$ treated in 6 rabbits

\begin{tabular}{|c|c|c|c|}
\hline $\begin{array}{c}\text { Kinetic } \\
\text { parameter }\end{array}$ & Unit & Ciprofloxacin given alone & $\begin{array}{l}\text { Ciprofloxacin + diclofenac } \\
\text { combined administration }\end{array}$ \\
\hline $\begin{array}{l}C^{0} \\
P\end{array}$ & $\mu \mathrm{g} / \mathrm{ml}$ & $12.27 \pm 0.24$ & $11.50 \pm 0.53$ \\
\hline $\boldsymbol{A}$ & $\mu \mathrm{g} / \mathrm{ml}$ & $5.53 \pm 0.04$ & $8.26 \pm 0.12 * *$ \\
\hline $\boldsymbol{B}$ & $\mu \mathrm{g} / \mathrm{ml}$ & $6.75 \pm 0.06 * *$ & $3.24 \pm 0.10$ \\
\hline$\alpha$ & $\mathbf{h}^{-1}$ & $2.03 \pm 0.02$ & $1.40 \pm 0.05$ \\
\hline$\beta$ & $\mathbf{h}^{-1}$ & $0.29 \pm 0.001$ & $0.30 \pm 0.001$ \\
\hline$T_{1 / 2 a}$ & $\mathbf{h}$ & $0.34 \pm 0.001$ & $0.49 \pm 0.001 * *$ \\
\hline$T_{1 / z \beta}$ & h & $2.42 \pm 0.06$ & $2.35 \pm 0.11$ \\
\hline$A U C_{0-\infty}$ & $(\mu \mathrm{g} . \mathrm{h}) / \mathrm{ml}$ & $25.55 \pm 1.52 * * *$ & $16.28 \pm 1.47$ \\
\hline$M R T$ & $\mathbf{h}$ & $2.82 \pm 0.03$ & $2.07 \pm 0.12$ \\
\hline$V_{\text {d(area })}$ & $\mathrm{L} / \mathrm{kg}$ & $4.11 \pm 0.13$ & $6.24 \pm 0.22 * *$ \\
\hline$V_{c}$ & $\mathrm{~L} / \mathrm{kg}$ & $2.44 \pm 0.001$ & $2.61 \pm 0.002$ \\
\hline$V_{d s s}$ & L/kg & $1.49 \pm 0.004$ & $1.67 \pm 0.001$ \\
\hline$C l_{B}$ & $(\mathrm{ml} / \mathrm{h}) / \mathrm{kg}$ & $1.17 \pm 0.001$ & $1.84 \pm 0.001 * *$ \\
\hline
\end{tabular}

Pharmacokinetic parameters as described by Baggot (1977), Gibaldi \& Perrier (1982), $C^{0}$ : the plasma drug concentration immediately after i.v. administration, A: zero time plasma drug concentration intercept of regression line of absorption phase, B: zero time intercept of the regression line of the elimination phase, $\alpha$ and $\beta$ : are the first-order rate constants related to the distribution and elimination phases respectively, $\mathrm{T}_{1 / 2} \alpha$ and $\mathrm{T}_{1 / 2 \beta}$ : are the half-lives of distribution and elimination respectively, AUC $0-\infty$ : area under the curve, MRT: mean residential time, td: total duration of pharmacological action, $\mathrm{V}_{\mathrm{d}(\text { area) }}$ : volume of distribution based on the total area under the plasma drug concentration time curve, $\mathrm{V}_{\mathrm{c}}$ : volume of central compartment, $\mathrm{V}_{\mathrm{dss}}$ : volume of distribution at steady state , $\mathrm{Cl}_{\mathrm{B}}$ : total body clearance ${ }^{* *} \mathrm{p} \leq 0.05, * * * \mathrm{p} \leq 0.001$.

$\overline{\text { Kafrelsheikh Vet. Med. J. Vol. } 9 \text { No. } 1 \text { (2011) }}$ 
Fig. (1). Comparative semilogarithmic plot depicting the concentration-time profile of ciprofloxacin in plasma of control and diclofenac treated rabbits ( $\mathrm{n}=6)$ following i.v. administration $\left(30 \mathrm{mg} \mathrm{kg}^{-1}\right)$

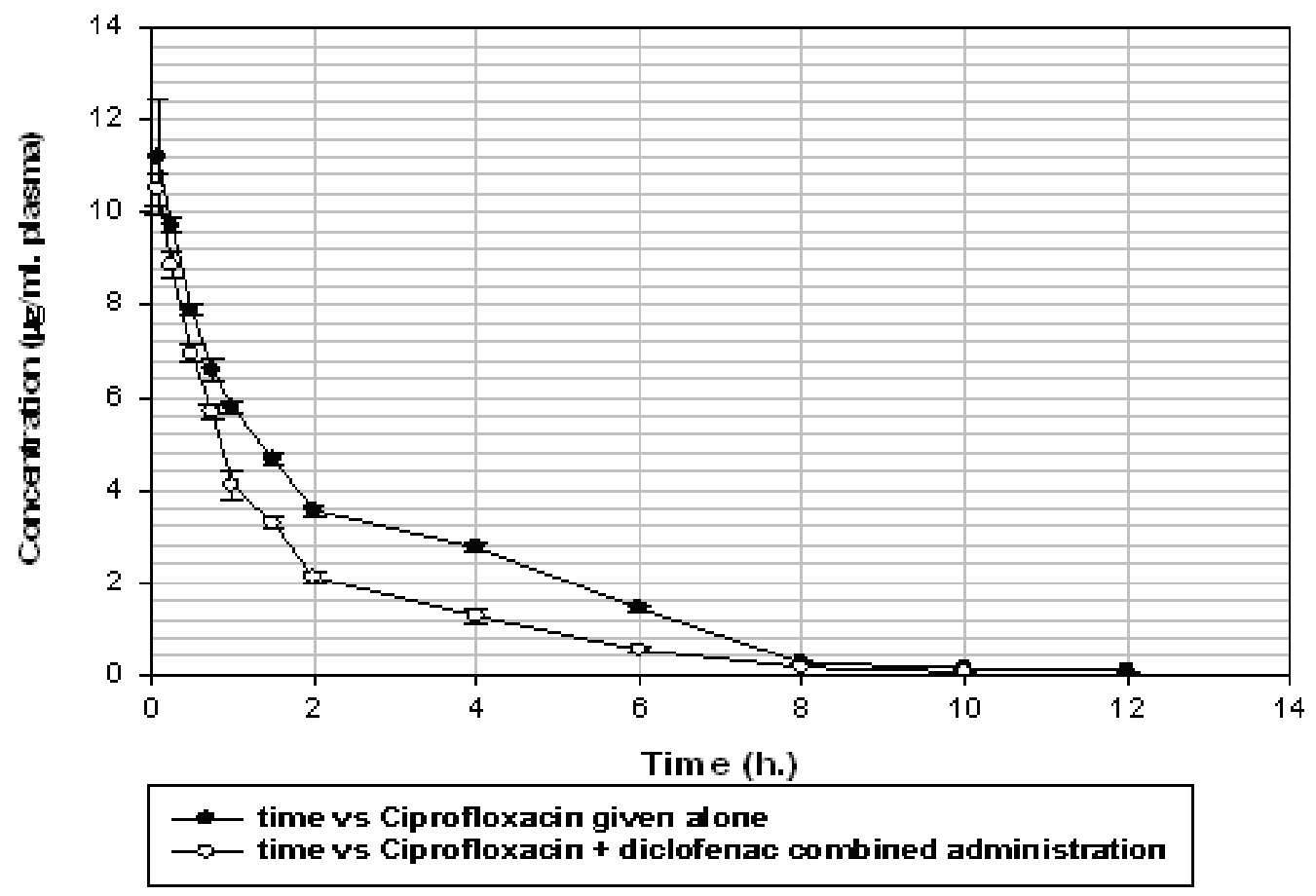

\section{REFERENCES}

- Abd El-Aty AM, Goudah A, Ismail M, Shimoda M (2003): Disposition kinetics of difloxacin in rabbit after intravenous and intramuscular injection of Dicural. Vet Res Commun 29: 297-304.

- Albarellos GA, Kreil VE, Landoni MF (2004): Pharmacokinetics of ciprofloxacin after single intravenous and repeat oral administration to cats. J Vet Pharmacol Ther 27: 155-162. 
- Baggot JD (1977): Principles of drug disposition in domestic animals. In: The basis of veterinary clinical pharmacology, WB Saunders, Philadelphia, p. 144-189.

- Baker SK, Niazi S (1983): Effect of water deprivation on aspirin disposition kinetics. J Pharm Sci 72: 1030-1034.

- Bashir S, Jamshaid M, ahmad B, Iqbal J (2008): Pharmacokinetics of ciprofloxacin in normal rabbits and changes observed in induced dehydrated state. Pak J Pharm Sci 21: 225-229.

- Blaser J, Dudley MN, Gilbert D, Zinner S H (1986): Influence of medium and method on the in vitro susceptibility of Pseudomonas aeruginosa and other bacteria to ciprofloxacin and enoxacin. Antimicrob Agents Chemother 29: 927-929.

- Boelsterli UA. (2003): Diclofenac-induced liver injury: a paradigm of idiosyncratic drug toxicity, Toxicol Appl Pharmacol 192: 307-322.

- Bort R, Ponsoda X, Jover R, Gómez-Lechón MJ, Castell JV( 1999): Diclofenac toxicity to hepatocytes: a role for drug metabolism in cell toxicity. J Pharmacol Exp Ther 288: 65-72.

- Campoli-Richards DM, Monk JP, Price A, Benfield P, Todd PA, Ward A (1988): Ciprofloxacin. A review of its antibacterial activity, pharmacokinetic properties and therapeutics use. Drugs, 35: 373-447.

- Carbon C, Dromer F, Brion N, Cremieux AC, Contrepois A (1984): Renal disposition of ceftazidime illustrated by interferences by probenecid, furosemide and indomethacin in rabbits. Anti Microb Agent Chemother 26: 373-377. 
- Connell JM, Whitworth JA, Davies DL, Lever AF, Richards AM, Fraser $\boldsymbol{R}$ (1987): Effects of ACTH and cortisol administration on blood pressure, electrolyte metabolism, atrial natriuretic peptide and renal function in normal man. J Hypertens 5: 425-433.

- Craig WA, Suh B (1991):Protein binding and the antibacterial effects. Methods for the determination of protein binding. In: Lorian, V. (Ed.), Antibiotics in laboratory medicine. Williams and Wilkins, Baltimore, MD, p. 367-402.

- Craig WA (1998): Pharmacokinetic/pharmacodynamic parameters: rationale for antibacterial dosing of mice and men. Clin Infec Dis 26: $1-12$.

- Goldstein EJC, Citron DM (1988): Comparative Activities of Cefuroxime, Amoxicillin-Clavulanic Acid, Ciprofloxacin, Enoxacin, and Ofloxacin against Aerobic and Anaerobic Bacteria Isolated from Bite Wounds. Anti Microb Agent Chemother 32 : 1143-1148.

- El-Banna HA (1999): Pharmacokinetic interactions between flunixin and sulphadimidine in horses. Deutsche Tierärztliche Wochenschrift 106: 400-403.

- Elmas M, Yazar E, Uney K, Karabacak A, Traş B (2008): Pharmacokinetics of enrofloxacin and flunixin meglumine and interactions between both drugs after intravenous co-administration in healthy and endotoxaemic rabbits. The Veterinary Journal 177: $418-424$. 
- Furst DE (1997): Meloxicam: selective COX-2 inhibition in clinical practice, Semin Arthritis Rheum 26: 21-27.

- Gibaldi M, Perrier D (1982): Pharmacokinetics. 2 $2^{\text {nd }}$ ed., MarcelDekker, New York,p. 45-109.

- Haghgoo S, Hasegawa T, Nadar M, Wang L, Nabeshima T, Kato N (1995): Effect of a bacterial lipopolysaccharide on biliary excretion of a $\beta$-lactam antibiotic, cefoperazone, in rats. Anti Microb Agent Chemother 39: 2258-2261.

- Hickey EJ, Raje RR, Reid VE, Gross SM, Ray SD (2001): Diclofenac induced in vivo nephrotoxicity may involve oxidative stress-mediated massive genomic DNA fragmentation and apoptotic cell death. Free Radic Biol Med 31: 139-152.

- Hyatt JM, Nix DE, Schentag JJ (1994): Pharmacokinetics and pharmacodynamics activities of ciprofloxacin against strains of Streptococcus pneumonia, Staphylococcus aureus and Pseudomonas aeruginosa for which MICs are similar. Anti Microb Agent Chemother 38: 2730-2737.

- Irfan N, Ahmad M, Qamar S, Muzaffar N, Akhtar N (1999): Changes in the pharmacokinetics of piroxicam in dehydrated rabbits. Acta Pharm. Turcica XLI 2: 54-57.

- Kampmann J, Molhom Hansen J, Siersbock-Nielsen K, Laursen H. (1972): Effect of some drugs on penicillin half-life in blood. Clinical Pharmacokinetics 2: 252-268. 
- Kang SL, Rybak MJ, McGrath BJ, Kaatz GW, Seo SM (1994):

Pharmacodynamics of levofloxacin, ofloxacin, and ciprofloxacin, alone and in combination with rifampin, against methicillinsusceptible and -resistant Staphylococcus aureus in an In Vitro Infection Model . Anti Microb Agent Chemother 38: 2702-2709.

- Kumar R, Aneja KR, Roy P, Sharma M, Gupta R, Ram S (2002): Evaluation of minimum inhibitory concentration of quinolones and third generation cephalosporins to Salmonella typhi isolates. Indian J Med Sci 56: 1-8

- Kung K, Riond JL, Wanner M (1993): Pharmacokinetics of enrofloxacin and its metabolite ciprofloxacin after intravenous and oral administration of enrofloxacin in dogs. Journal of Veterinary Pharmacology and Therapeutics 16: 462-468.

- Lin EN, Annette SV, Barry H, Kim PW (2006): Action of diclofenac on kidney mitochondria and cells. Biochemical and Biophysical Research Communications 348: 494-500.

- Lode H, Borner K, Koeppe P (1998): Pharmacodynamics of fluoroquinolones. Clinical Infectious Disease 27: 33-39.

- Miyazaki Y, Horii Y, Ikenaga N, Shimoda M, Kokue E (2001): Possible active transport mechanism in pharmacokinetics of flunixinmeglumine in rabbits. Journal Veterinary Medical Science 63: $885-888$.

- Neu HC ( 1987): Ciprofloxacin: a major advance in quinolone chemotherapy. Am J Med 82 (Suppl. 4A):1. 
- Oaks JL, Gilbert M, Virani MZ, Watson RT, Meteyer CU, Rideout BA, Shivaprasad BA, Ahmed HL, Chaudhry S, Arshad MJ, Mahmood M, Ali SA, Khan AA (2004): Diclofenac residues as the cause of vulture population decline in Pakistan. Nature 427: 630-633.

- Ogino T, Mizuno Y, Ogata T, Takahashi Y (2005): Pharmacokinetic interactions of flunixin meglumine and enrofloxacin in dogs. American Journal of Veterinary Research 66: 1209-1213.

- Post LO, Farrell CV, Baker JD, Myers MJ (2003): The effect of endotoxin and dexamethasone on enrofloxacin pharmacokinetic parameters in swine. Journal of Pharmacology and Experimental Therapeutics 304: 889-895.

- Ramon J, Dautrey S, Farinoti R, Carbon C, Rubinstein E (1996): Excretion of Ciprofloxacin into the Large Bowel of the Rabbit. Anti. Microb. Agent. Chemother 40: 11-13.

- Rao GS, Ramesh S, Ahmad AH, Tripathi HC, Sharma LD, Malik JK (2000): Effects of endotoxin-induced fever and probenecid on disposition of enrofloxacin and its metabolite ciprofloxacin after intravascular administration of enrofloxacin in goats. Journal of Veterinary Pharmacology and Therapeutics 23: 365-372.

- Riddle C, Lemons C L, Papich M G, Altier C (2000): Evaluation of Ciprofloxacin as a Representative of Veterinary Fluoroquinolones in Susceptibility Testing. Journal of clinical microbiology 38: 16361637. 
- Riess W, Stierlin H, Degen P, Faigle JW, Gérardin A, Moppert J, Sallmann A, et al. (1978): Pharmacokinetics and metabolism of the anti-inflammatory agent voltaren. Scand J Rheumatol 22 (Suppl): 17-29.

- Schmitz G, Stauffert I, Sippel H, Lepper H, Estler CJ (1992): Toxicity of diclofenac to isolated hepatocytes. J Hepatol 14: 408-409.

- Schwaiger J, Ferling H, Mallow U, Wintermayr H, Negele RD (2004): Toxic effects of the non-steroidal anti-inflammatory drug diclofenac.Part I: histopathological alterations and bioaccumulation in rainbow trout. Aquat Toxicol 68: 141-150.

- Soma LR, Behrend E, Rudy J, Sweeney RW (1988): Disposition and excretion of flunixin meglumine in horses. American Journal of Veterinary Research 49: 1894-1898.

- Stierlin H, Faigle JW, Sallman A, Küng W, Richter WJ, Kriemler HP, Alt KO et al. (1979): Biotransformation of diclofenac sodium, Voltaren in animals and man I Isolation and identification of principal metabolites. Xenobiotica 9: 601-10.

- Taib NT, Jarrar BM, Mubarak MM (2004): Ultrastructural alterations in renal tissues of rabbits induced by diclofenac sodium (Voltaren). Saudi Med J 25: 1360-1365.

- Turnidge J (1999): Pharmacokinetics and pharmacodynamics of fluoroquinolones. Drugs 58: 29-36. 
- Vancutsem PM, Babish JG, Schwark WS (1990): The fluoroquinoloneantimicrobials: structure, antimicrobial activity, pharmacokinetics,clinical use in domestic animals and toxicity. Cornell Veterinarian 80: 173-186.

- Walker RD (2000): Fluoroquinolones. In: JF Prescott, JD Baggot, RD Walker (Eds.), Antimicrobial Therapy in Veterinary Medicine, $3^{\text {rd }}$ ed. Iowa State University Press, Ames, USA, p. 315-338.

- Wallace JL(1997): Non-steroidal anti-inflammatory drugs and gastroenteropathy: the second hundred years. Gastroenterology 112: 1000-1016.

- Warner TD, Mitchell JA (2008): COX-2 selectivity alone does not define the cardiovascular risks associated with non-steroidal antiinflammatory drugs. Lancet 371: 270.

- Whittem T, Firth EC, Hodge H, Turner K (1996): Pharmacokinetic interactions between repeated dose phenylbutazone and gentamicin in the horse. Journal of Veterinary Pharmacology and Therapeutics 19: 454-459.

- Yoon WH, Yoon EJ, Jang SH, Lee SH, Lee HJ, Park JM, Choi KE, Lee MG (1994): Pharmacokinetics of ciprofloxacin after intravenous administration of ciprofloxacin-TOF in rabbits. International journal of pharmaceutics 102: 249-255. 